http://journal.uinsgd.ac.id/index.php/biodjati

\title{
THE FIRST RECORD OF Metaphire birmanica (Rosa, 1888) IN VIETNAM, WITH NOTES ON SEVERAL EARTHWORM SPECIES
}

\author{
Dang Hai Lam ${ }^{1 *}$, Anh Duc Nguyen ${ }^{2}$, Tung Thanh Nguyen ${ }^{3}$
}

Received : April 01, 2020

Accepted : May 08, 2020

DOI: 10.15575/biodjati.v5i1.8111

${ }^{1,3}$ Department of Biology, School of Education, Can Tho University, Can Tho city, Vietnam

${ }^{2}$ Institute of Ecology and Biological Resources, Vietnam Academy of Science and Technology, 18, Hanoi, Vietnam

e-mail:

*1lamhaidangct@gmail.com

²ducanh410@yahoo.com

thanhtung@,ctu.edu.vn

*Corresponding author
Abstract. The Amynthas and Metaphire species recorded in Vietnam have been rechecked based on original descriptions and preserved specimens. As a result, Metaphire birmanica (Rosa, 1888) is recorded in Vietnam for the first time. The species is recognized by having three pairs of spermathecal pores in 5/6/7/8, male pores in xviii, presence of copulatory pouches, no genial markings, and manicate intestinal caeca. In addition, three species have been rechecked and re-assigned to different genera, namely Amynthas tripidoporophoratus (Thai \& Nguyen, 1993) comb. nov., Metaphire dranfocana (Do \& Huynh, 1993) comb. nov., Metaphire anhumalatana (Thai \& Huynh, 1993) comb. nov.

Keywords: Amynthas, biodiversity, Megascolecidae, Metaphire, Pheretima, taxonomy, Vietnam

\section{Citation}

Lam, D. H., Nguyen, A. D. \& Nguyen, T. T. (2020). The First Record of Metaphire birmanica (Rosa, 1888) in Vietnam, with Notes on Several Earthworm Species. Jurnal Biodjati, 5(1), 15-22.

\section{INTRODUCTION}

Almost all earthworms of Vietnam belong to the Pheretimoid group in the family Megascolecidae (207 species) (Nguyen et al., 2016a, 2016b, 2017, 2018, 2019; Nguyen \& Lam, 2017; Lam et al., 2018). Prior to Nguyen et al. (2016), all Pheretimoid species were classified to only one genus Pheretima Kinberg, 1867 (Thai \& Tran, 1986; Do, 1994; Nguyen, 1994; Le, 1995; Pham, 1995; Huynh, 1996; Thai, 2000). Although Blakemore (2007) tried to re-classify the Vietnamese earthworms in accordance with the system of Sims \& Easton (1972), he seemed to have very superficial work because of lacking descriptive information and examining speci- mens. Nguyen et al (2016) provided the comprehensive checklist of the Vietnamese earthworms, all Pheretimoid species were listed in 6 genera including two argumentative genera, Amynthas (112 species) and Metaphire (54 species). In this list, several species were still placed in the same genera following the suggestions of Blakemore (2007). After checking specimens housed in the Can Tho University, we found that the generic positions of several species were wrong, and those species need to be confirmed with new information. Therefore, this work aimed to clarify the generic position of several species and additionally contributes a new record to the earthworm fauna of Vietnam. 


\section{Jurnal Biodjati 5(1):15-22, May 2020 \\ JURNAL BI@DIATI}

http://journal.uinsgd.ac.id/index.php/biodjati

\section{MATERIALS AND METHODS}

All species of two genera Amynthas and Metaphire listed in Blakemore (2007) and Nguyen et al. (2016) were rechecked using the original descriptions and preserved specimens including holotypes and paratypes. Samples observed in this study are being kept in the Laboratory of Zoology, Department of Biology, School of Education, Can Tho University. Earthworms were externally observed, dissected, and photographed under a microscope (Motic DM143-FBGG-C). For those species without preserved specimens, we used their original paper and confirmed it with species' authors. Colour images of specimens and original drawings were provided for the better illustrative comparison.
Abbreviations: $\mathrm{A}=$ Aclitellate specimen; $\mathrm{C}=$ Clitellate specimen; $\mathrm{CTU}=\mathrm{Can}$ Tho University, Can Tho, Vietnam; SORC = Soil Organism Research Center, Hanoi, Vietnam; ag = accessory gland; amp = ampulla; $\mathrm{dv}=$ diverticulum; $\mathrm{gm}=$ genital markings; $\mathrm{mp}$ $=$ male pore; $\mathrm{pn}=$ penis; $\mathrm{sg}=$ seminal groove; $\mathrm{sp}=$ spermathecal pore.

\section{RESULTS AND DISCUSSION}

\section{Taxonomic Part}

Family: Megascolecidae (Rosa, 1891)

Genus: Metaphire (Sims \& Easton, 1972)

Metaphire birmanica (Rosa, 1888)

(Figure 1, Table 1)

Perichaeta birmanica Rosa, 1888: 164.

Pheretima birmanica -- Gates, 1972: 207.

Metaphire birmanica -- Sims \& Easton, 1972: 239; Blakemore, 2007: 15.

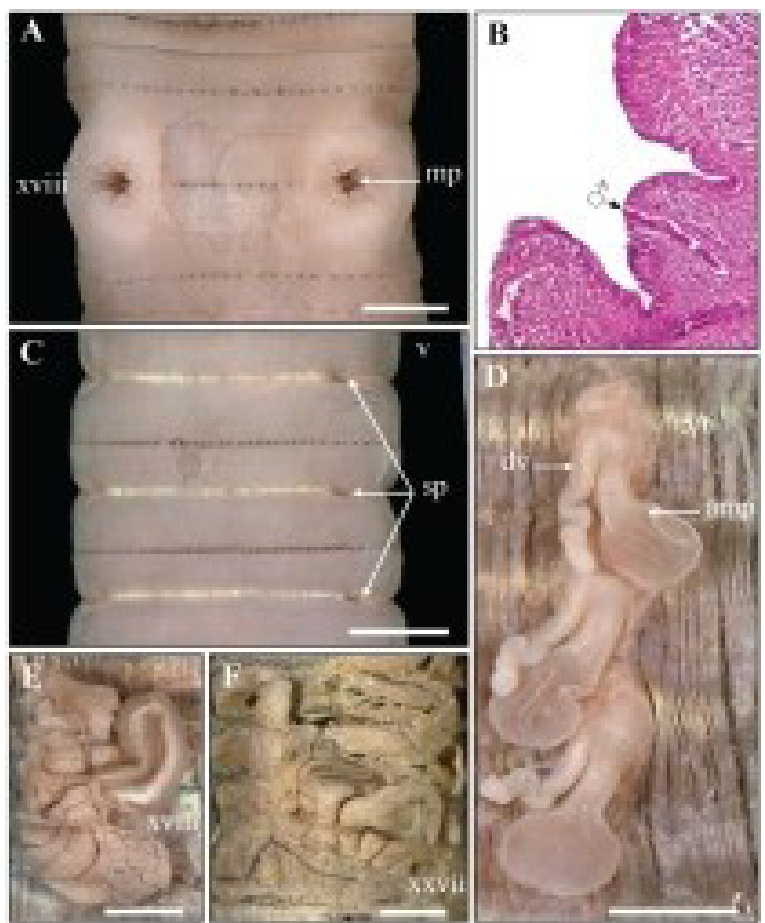

Figure 1. Metaphire birmanica (Rosa, 1888)(A. Male region, ventral view; B. The copulatory pouch, transverse body section; C. Spermathecal region, ventral view; E. Prostate gland, left side; F. Intestinal caecum) 


\section{JURNAL BIDDJATI}

http://journal.uinsgd.ac.id/index.php/biodjati

Type locality: Myanmar (Bhamof) (Rosa, 1888).

Type materials: Genoa Museum, Italy.

Examined material: 3C (CTU-EW.165.01), Thong Thu commune, Que Phong district, Nghe An province, 21/7/1987, coll. unknown.

History of materials: No record

Diagnosis: Medium-sized worm, length 92-98 mm, diameter 4.4-4.6 mm, 141-168 segments. Prostomium epilobous. First dorsal pore in $11 / 12$. Three pairs of spermathecal pores in ventrolateral intersegment 5/6/7/8. Male pores in xviii; copulatory pouches present. Genital markings absent in both spermathecal and male regions. Holandric. Testis sacs separated. Intestinal caeca manicate. Septa 8/9/10 aborted.

\section{Re-description}

External characters: Body cylindrical, medium-sized, length $92-98 \mathrm{~mm}$, diameter 4.4-4.6 mm, weight $0.7-1.0 \mathrm{~g}, 141-168 \mathrm{seg}-$ ments. Dorsum greyish, ventrum paler. Prostomium epilobous. First dorsal pore in 11/12. Pre-clitellum setae thinner and denser than post-clitellar ones; setal numbers: 109-117 in viii, 89-94 in xxx, 9-11 between two male pores in ventral xviii; setal distance $a a=a b$, $\mathrm{zz}=\mathrm{zy}$. Clitellum annular, $\mathrm{xiv}-\mathrm{xvi}$ without setae and dorsal pores. Female pore single, in midventral xiv.

Three pairs of spermathecal pores in ventrolateral intersegment 5/6/7/8. Male pores located inside copulatory pouches which opened in the setal ring xviii; ventral distance between two openings of copulatory pouches about $0.35 \mathrm{x}$ body circumference. Genital markings absent in both spermathecal and male regions.

Internal characters: Septa 5/6/7/8 thick, 8/9/10 absent, 10/11/12/13 thin. Oesophageal gizzard within viii-X. Intestinal origin in $\mathrm{xv}$; caeca manicate within xxvii-xxiv. Last hearts in xiii. Pharyngeal micronephridia well de- veloped in 5/6/7. Typhlosole simple, lamelliform. Lymph glands present from 16/17.

Spermathecae paired in vi-viii. Ampulla oval-shaped, ducts about 1/2 ampulla length. Diverticula shorter than ampulla, strongly waved and directly attached to the base of ampulla duct; seminal chamber small, oval-shaped. No accessory glands.

Holandric. Testis sacs in $\mathrm{x}$ and $\mathrm{xi}$, separated. Seminal vesicles in xi and xii. Ovaries well developed in 12/13. Ovisacs are invisible. Prostate glands deeply lobuled, paired in xvixxii; duct U-shaped. Accessory glands absent. Distribution: Pakistan, Myanmar, China, Laos, Vietnam (Sarwar et al., 2006; Blakemore, 2006, 2007)

Vietnamese name: Giun miến điện

\section{Remarks}

Rosa (1888) described the species Perichaeta birmanica from poorly preserved samples from Burma (currently known as Myanmar). Those samples lack several important organs, and thus, intestinal caeca, prostomium, the ventral distance between male pores were missing in the original description. Gates (1972) re-described the species from newly collected samples in Myanmar. He provided the details of epilobous prostomium, manicate caeca, the ventral distance of male pores about 0.35 body circumference, and copulatory pouches. Recently, this species was also re-described from samples collected in Thailand (Bantaowong et al., 2011), but with the ventral distance between spermathecal pores, and between male pores of about 0.42 body circumference.

Although Blakemore (2006) listed the presence of this species in Vietnam, he has never checked specimens or explained the absence of this species in previous reports. Both the comprehensive checklists of Thai (2000) and Nguyen et al. (2016) did not list the species Metaphire birmanica, in Vietnam. There- 


\section{Jurnal Biodjati 5(1):15-22, May 2020 \\ JURNAL BI@DIATI}

http://journal.uinsgd.ac.id/index.php/biodjati

fore, we believe that the species has been never officially reported from Vietnam.

After checking the samples deposited in the Can Tho University, we found that these samples belong to the species, Metaphire birmanica. Our samples almost agree with the original description, with Gates (1972), and Bantaowong et al. (2011) except for several minor differences. The Vietnamese specimens slightly differ from the descriptions of Rosa
(1888) and Gates (1972) in the first dorsal pore (11/12 vs. 12/13), more segments (141-168 vs. 112), and the longest part of caeca (first vs second). Our samples are also different from Thailand ones (Bantaowong et al., 2011) in the distance of spermatheca pores $(0.3 \mathrm{X}$ vs. $0.4 \mathrm{X}$ ); the shape of diverticula (zigzag vs. coiled) and the presence of lymph glands (absent vs. present). The detailed comparison is presented (Table 1).

Table 1. Characteristic comparison of Metaphire birmanica among Vietnamese specimens and others

\begin{tabular}{|c|c|c|c|c|}
\hline Characteristic & $\begin{array}{l}\text { Our specimens } \\
\text { (Vietnam) }\end{array}$ & $\begin{array}{c}\text { Rosa (1888) } \\
\text { (Myanmar) }\end{array}$ & $\begin{array}{l}\text { Gates (1972) } \\
\text { (Myanmar) }\end{array}$ & $\begin{array}{c}\text { Bantaowong et al. } \\
\text { (2011) } \\
\text { (Thailand) }\end{array}$ \\
\hline Length (mm) & $92-98$ & 130 & $100-160$ & $85-210$ \\
\hline Diameter (mm) & $4.4-4.6$ & 6 & $4-7$ & $5.8-6.7$ \\
\hline Segments & $141-168$ & 112 & 112 & $105-111$ \\
\hline Spermathecal pores & $5 / 6 / 7 / 8$ & $5 / 6 / 7 / 8$ & $5 / 6 / 7 / 8$ & $5 / 6 / 7 / 8$ \\
\hline $\begin{array}{l}\text { Ventral distance between } \\
\text { spermathecal pores }\end{array}$ & $0.35 \mathrm{X}$ & $0.42 \mathrm{X}$ & $0.35 \mathrm{X}$ & $0.45 \mathrm{X}$ \\
\hline Prostomium & Epilobous & $\mathrm{n} / \mathrm{a}$ & Epilobous & Epilobous \\
\hline First dorsal pore & $11 / 12$ & $12 / 13$ & $12 / 13$ & $12 / 13$ \\
\hline Pre-clitellum setae & $109-117$ & 70 & $70 ?$ & $65-70$ \\
\hline Post-clitellum setae & $89-94$ & 70 & $70 ?$ & $63-69$ \\
\hline Male pores & $\begin{array}{l}\text { xviii, on conical } \\
\text { penial body in small } \\
\text { copulatory pouch }\end{array}$ & $\begin{array}{l}\text { xviii, on slight- } \\
\text { ly bulging pale } \\
\text { areolas }\end{array}$ & $\begin{array}{l}\text { xviii, on conical } \\
\text { penial body in small } \\
\text { copulatory pouch }\end{array}$ & $\begin{array}{l}\text { xviii, onto the } \\
\text { tumescent lips }\end{array}$ \\
\hline $\begin{array}{l}\text { Ventral distance between } \\
\text { male pores }\end{array}$ & $0.35 \mathrm{X}$ & $0.42 \mathrm{X}$ & $?$ & $0.3 \mathrm{X}$ \\
\hline Genital markings & Absent & Absent & Absent & Absent \\
\hline Ampulla & Oval & Oval & $?$ & Large sac \\
\hline Shape of diverticulum & Zigzag & Convoluted tube & Looped, zigzag & Coiled \\
\hline Caeca (parts) & $\begin{array}{l}\text { Manicate } \\
\text { (4-6 parts) }\end{array}$ & $?$ & $\begin{array}{l}\text { Manicate } \\
(3-6 \text { parts })\end{array}$ & $\begin{array}{l}\text { Manicate } \\
(3-6 \text { parts })\end{array}$ \\
\hline Longest parts of caeca & First & $?$ & Second & Second \\
\hline Male organ system & Holandric & Holandric & Holandric & Holandric \\
\hline Testis sacs & Separated & $?$ & Unpaired? & Paired \\
\hline Last heart & xiii & $?$ & xiii & xiii \\
\hline Origin of intestine & $\mathrm{XV}$ & $?$ & $\mathrm{xV}$ & $\mathrm{xV}$ \\
\hline Typhlosole & Lameliform & $?$ & Lameliform & Present \\
\hline Prostate glands & $\begin{array}{l}\text { Deeply lobuled in } \\
\text { xvi-xxii }\end{array}$ & $\begin{array}{l}\text { Deeply lobuled in } \\
3 \text { segments }\end{array}$ & $\begin{array}{l}\text { Deeply lobuled in } \\
\text { xvi-xx }\end{array}$ & $\begin{array}{l}\text { Deeply lobuled in } \\
\text { xvii-xxi }\end{array}$ \\
\hline Prostatic duct & U-shaped & Curved & U-shaped loop & U-shaped \\
\hline Lymph glands & Absent & $?$ & $?$ & Post caecal segment \\
\hline
\end{tabular}

Lam et al. 


\section{Jurnal Biodjati 5(1):15-22, May 2020 \\ JURNAL BI@DIATI}

http://journal.uinsgd.ac.id/index.php/biodjati

Metaphire anhumalatana (Thai \& Huynh, 1993) comb. nov. (Figure 2-A)

Pheretima anhumalatana Thai \& Huynh, 1993 (in: Thai et al., 1993): 14, fig. 1D; Thai, 2000: 307.

Amynthas anhumalatanus -- Nguyen et al., 2016: 14

Amynthas? anhumalatanus -- Blakemore 2007: 7.

Type locality: Vietnam (Dak Lak: Yok Don province) (Thai et al., 1993).

Type materials: lost.

Examined material: no

History of materials: SORC, Vietnam. (Nguyen et al., 2016)

Diagnosis: Medium-sized worm, length 110 $\mathrm{mm}$, diameter $3.0-3.5 \mathrm{~mm}, 120$ segments. Prostomium epilobous. First dorsal pore in $12 / 13$. Four pairs of spermathecal pores in ventrolateral intersegment 5/6/7/8/9. Male pores in xviii; copulatory pouches present. Genital markings absent. Intestinal caeca simple. Septa 8/9/10 absent.

Distribution: Only known from Vietnam.

Vietnamese name: Giun cận nhumalat (Nguyen et al., 2016).

Remarks: Blakemore (2007) put the species into the genus Amynthas, but still with a question mark: Amynthas? anhumalatanus. Nguyen et al. (2016) confirmed this placement. However, it was a mistake because Thai et al. (1993) already mentioned male pores located inside copulatory pouches "Lỗ đưc trong buồng giao phối" (Figure 2-A). They also remarked that paratypes had variations in the number of spermathecal pores. One individual has 3 pairs of spermathecal pores in $5 / 6 / 7 / 8$ while another has 4 pairs in 5/6/7 and 8/9/10.

Metaphire dranfocana (Do \& Huynh, 1993) comb. nov. (Figure 2-B).

Pheretima dranfocana Do \& Huynh, 1993 (in Thai et al. 1993): 12, fig. 1A; Thai, 2000: 308.
Amynthas dranfocanus -- Nguyen et al., 2016: 25.

Amynthas? dranfocanus -- Blakemore, 2007: 31.

Type locality: Vietnam (Dak Lak: Yok Don province) (Thai et al., 1993).

Type materials: CTU, Vietnam.

Examined material: 1C holotype (CTUEW.134.h01) and 1C paratype (the tail was lost) (CTU-EW.134.p02) natural forest, Drang Phok village, Krong Na commune, Buon Don district, Dak Lak province, 01/10/1989, coll. Huynh Thi Kim Hoi.

History of materials: 2C (SORC-HPV.040) same data as for holotype and paratype (Nguyen et al., 2016).

Diagnosis: Medium-sized worms. Length $110 \mathrm{~mm}$, diameter ca. $3.0 \mathrm{~mm}, 75$ segments. Prostomium epilobous. First dorsal pore in $12 / 13$. Two pairs of spermathecal pores in ventrolateral intersegment 7/8/9. Male pores in xviii; copulatory pouches present. Two pre-setal pairs of genital markings in xviii and xix. Holandric. Testis sacs separated. Intestinal caeca simple. Septa 8/9/10 absent.

Distribution: Only known from Vietnam. Vietnamese name: Giun đrăng phốk.

Remarks: Blakemore (2007) put the species into the genus Amynthas, but still with a question mark: Amynthas? dranfocanus. Nguyen et al. (2016) confirmed this placement. However, it is a mistake because Thai et al. (1993) already mentioned male pores located deeply inside copulatory pouches ("Lô đực ở đáy buồng giao phối sâu") and prostatic ducts enlarged basally and ending in a coelomic copulatory chamber ("gốc cuống nổi rõ buồng giao phối") (Thai et al., 1993).

Genus: Amynthas Kinberg, 1867

Amynthas tripidoporophoratus (Thai \& Nguyen, 1993) comb. nov. (Figure 2-C).

Pheretima tripidoporophorata Thai \& Nguy- 


\section{JURNAL BIDDJATI}

http://journal.uinsgd.ac.id/index.php/biodjati

en, 1993 (in Nguyen, 1993): 5, fig. 1A; Pham, 1995: 95; Nakamura, 1999: p. 24; Thai, 2000: 310.

Metaphire tripidoporophoratus (sic!) -Nguyen et al., 2016: 68.

Amynthas? tripidoporophoratus -- Blakemore 2007: 100.

Type locality: Vietnam (Thua Thien Hue: Hue city) (Nguyen, 1993).

Type material: CTU, Vietnam.

Examined material: 6C (CTU-EW.141.01) An Le, Huong Dien, Hue, 15/5/1985, coll. Nguyen Van Thuan.

History of materials: $6 \mathrm{C}$ and $1 \mathrm{~A}$ (SORC-V.095.04) same data as for (CTUEW.141.01) (Nguyen et al., 2016).

Diagnosis: Medium-sized worm, length 55-71 mm, diameter $2.0-3.8 \mathrm{~mm}, 119-147$ segments. Prostomium epilobous. First dorsal pore in $12 / 13$. One pre-setal pair of spermathecal pores in ventrolateral vi. Male pore with short penis located on triangle porophore included longitudinal and transversal seminal grooves in xviii; copulatory pouches absent. Genital markings absent. Holandric. Testis sacs connected. Intestinal caeca simple. Septa 8/9/10 absent.

Distribution: Only known from Vietnam.

Vietnamese name: Giun nhú đực 3 cánh (Nguyen et al., 2016).

Remarks: The species was described as Pheretima tripidoporophorata, then transferred to the genus Amynthas by Blakemore (2007) with the question mark "Amynthas? tripidoporophoratus". Nguyen et al. (2016) transferred this species to the genus Metaphire but in the misspelled name "Metaphire tripidoporophoratus". After rechecking specimens, we found that the species lacks copulatory pouches. Therefore, the species should be in the genus Amynthas.
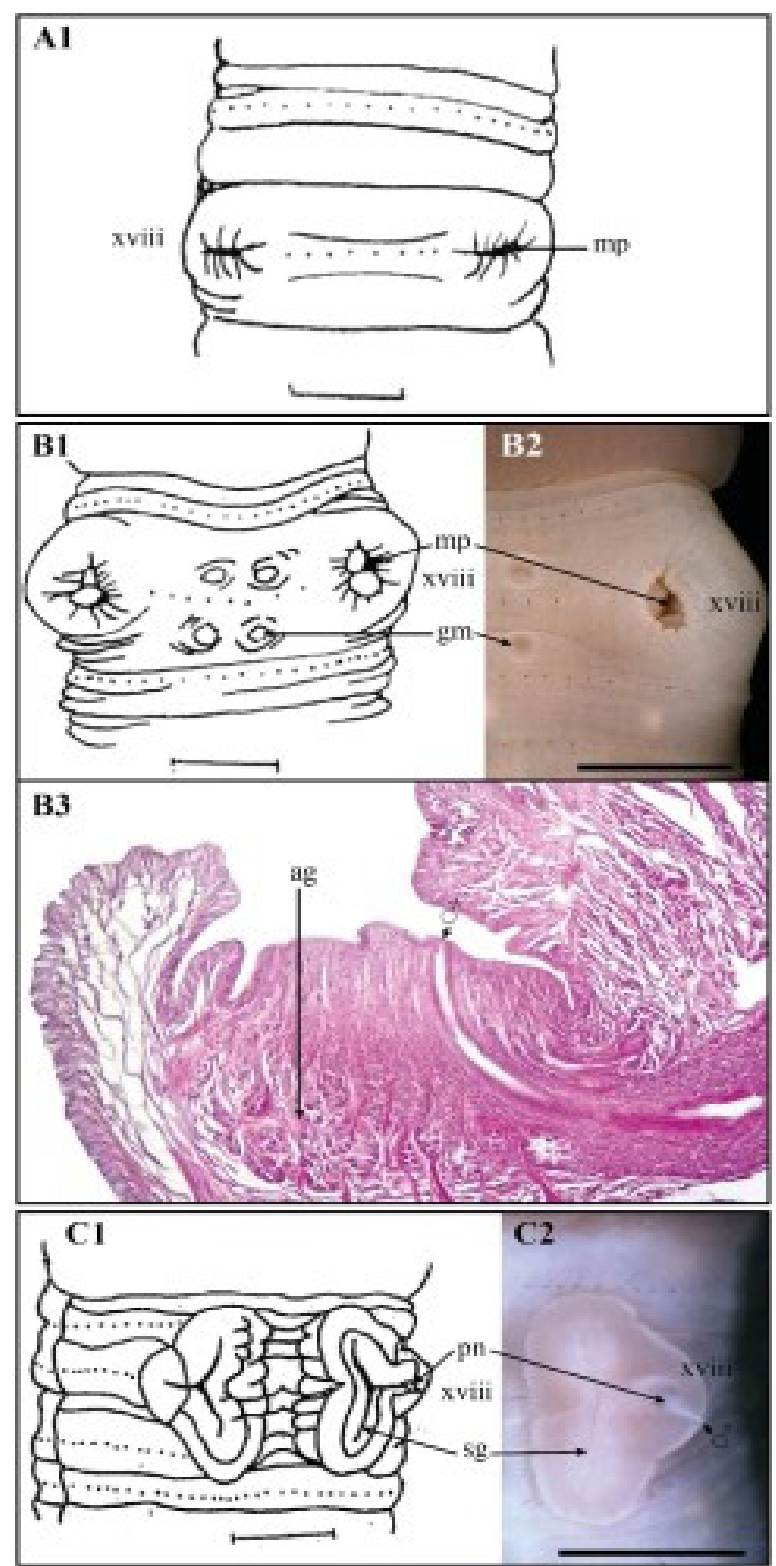

Figure 2. Male pores region of A-Metaphire anhumalatana (Thai \& Huynh, 1993), B-Metaphire dranfocana (Do \& Huynh, 1993) and C-Amynthas tripidoporophoratus (Thai \& Nguyen, 1993) (A1, B1. after Thai et al., 1993; C1. after Nguyen, 1993; B2, C2. from samples; C3. The copulatory pouch, transverse body section from sample) 


\section{Jurnal Biodjati 5(1):15-22, May 2020 \\ JURNAL BI@DIATI}

http://journal.uinsgd.ac.id/index.php/biodjati

With the re-confirmation of the generic position of three species and the discoveries of Metaphire birmanica, the number of earthworm species increases to 220 in Vietnam, of which the genus Amynthas has 111 species, Metaphire has 56 species. However, the earthworm fauna of Vietnam is far from fully understanding, more intensive studies will reveal more new discoveries.

\section{ACKNOWLEDGEMENTS}

Authors thank to Mr. Isma Dwi Kurniawan for his kindly helping to improve the early manuscript. This research is funded by the Vietnam National Foundation for Science and Technology Development (NAFOSTED) under the grant 106.05-2018.04. This study is also funded in part by the Can Tho University Improvement Project VN14-P6, supported by a Japanese ODA loan.

\section{REFERENCES}

Bantaowong, U., Chanabun, R., Tongkerd, P., Sutcharit, C., James, S. W. \& Panha, S. (2011). A New Species of the Terrestrial Earthworm of the Genus Metaphire Sims and Easton, 1972 from Thailand with Redescription of Some Species. Tropical Natural History, 11(1), 55-69.

Blakemore, R. J. (2006). A Series of Searchable Texts on Earthworm Biodiversity, Ecology and Systematics from Various Regions of the World (Vol. 2). CD-ROM publication by Ito, M.T. and Kaneko, $N$. (eds). Japan: Soil Ecology Research Group, Graduate School of Environment \& Information Sciences, Yokohama National University, 79-7 Tokiwadai, Yokohama 240-8501.

Blakemore, R. J. (2007). Updated checklist of Pheretimoids (Oligochaeta: Megascole- cidae: Pheretima auct.) taxa. Retrieved from http://www.annelida.net/earthworm/Pheretimoids.pdf.

Do, N. V. (1994). The Earthworm Fauna of Northwest Vietnam. PhD. Dissertation. Hanoi National University of Education.

Gates, G. E. (1972). Burmese Earthworms: An Introduction to the Systematics and Biology of Megadrile Oligochaetes with Special Reference to Southeast Asia. Transactions of the American Philosophical Society, 62(7), 1-326.

Huynh, H. T. K. (1996). The Earthworm Fauna of Southern Part of Central Vietnam. PhD. Dissertation. Hanoi National University of Education.

Lam, D. H., Nguyen, T. T., Hoang, S. V. \& Nguyen, A. D. (2018). Two New Earthworm Species of the Genus Polypheretima Michaelsen, 1934 (Clitellata: Megascolecidae) from Central Vietnam. Raffles Bulletin of Zoology, 66, 572579.

Le, T. V. (1995). The Earthworm Fauna of Northeastern Vietnam. PhD. Dissertation. Hanoi National University of Education.

Nakamura, Y. (1999). Checklist of Earthworms of Pheretima Genus Group (Megascolecidae: Oligochaeta) of the World. Japan: Edaphologia.

Nguyen, N. Q., Nguyen, T. V., Duong, T. C., Le, N. V. \& Nguyen, T. T. (2019). Species Diversity of Earthworms in Dong Nai Province, Vietnam. Tap Chi Sinh Hoc, 41, 117-129.

Nguyen, T. T, Lam, D. H. \& Nguyen, A. D. (2016b). On the Giant Pheretimoid Earthworms from Vietnam (Clitellata: Megascolecidae), with Descriptions of Three New Species. Zoological Studies, $55,1-13$. 


\section{Jurnal Biodjati 5(1):15-22, May 2020 \\ JURNAL BIDDJATI}

http://journal.uinsgd.ac.id/index.php/biodjati

Nguyen, T. T, Nguyen, A. D., Tran, B. T. T. \& Blakemore, R. J. (2016a). A Comprehensive Checklist of Earthworm Species and Subspecies from Vietnam (Annelida: Clitellata: Oligochaeta: Almidae, Eudrilidae, Glossoscolecidae, Lumbricidae, Megascolecidae, Moniligastridae, Ocnerodrilidae, Octochaetidae). Zootaxa, 4140(1), 1-92.

Nguyen, T. T, Trinh, K.-B. T., Nguyen, H.-L. T. \& Nguyen, A. D. (2017). Earthworms (Annelida: Oligochaeta) from Islands of Kien Hai District, Kien Giang Province, Vietnam, with Descriptions of Two New Species and One Subspecies. Journal of Natural History, 51(15-16), 883-915.

Nguyen, T. T. \& Lam, D. H. (2017). Three New Earthworm Species of the Genus Metaphire Sims \& Easton, 1972 (Oligochaeta, Megascolecidae) from Dong Nai Province, Vietnam. Tap Chi Sinh Hoc, 39(4), 406-415.

Nguyen, T. T., Nguyen, N. Q. \& Nguyen, D. A. (2018). First Record of the Earthworm Genus Pheretima Kinberg, 1867 Sensu Stricto in Vietnam, with Description of a New Species (Annelida: Clitellata: Megascolecidae). Zootaxa, 4496(1), 251-258.

Nguyen, T. V. (1993). Some New Species of Earthworms of Genus Pheretima Kinberg, 1867 (Megascolecidae-Oligochaeta) from Thua Thien-Hue, Vietnam. Tap Chi Sinh Hoc, 15(1), 5-8.

Nguyen, T. V. (1994). The Earthworm Fauna of Binh Tri Thien region. PhD. Dissertation. Hanoi National University of Education.
Pham, H. T. H. (1995). The Earthworm Fauna of Quang Nam-Da Nang. PhD. Dissertation. Hanoi National University of Education.

Rosa, D. (1888). Viaggio di Leonardo Fea in Birmanica e regioni vicine, V-Preichetidi. Annali Del Museo Civico Di Storia Naturale, Giacomo Doria, 6, 155-167.

Sarwar, M., Nadeem, A., Khalid Iqbal, K. \& Shafiq, T. (2006). Biodiversity of Earthworm Species Relative to Different Flora. Punjab Univ. J. Zool., 21(1-2), 1-7.

Sims, R.W. \& Easton, E.G. (1972). A numerical Revision of the Earthworm Genus Pheretima auct. (Megascolecidae: Oligochaeta) with the Recognition of New Genera and an Appendix on the Earthworms Collected by the Royal Society North Borneo Expedition. Biological Journal of the Linnean Society, 4, 169268.

Thai, B. T. \& Tran, C. B. (1986). The Fauna of Earthworms of Mountain District Ki Son (Nghe Tinh province, Vietnam) and Descriptions of New Species of the Genus Pheretima Kinberg. Tap Chi Sinh Hoc, 8(4), 4-12.

Thai, B. T. (2000). Species Diversity of Earthworms in Vietnam. Proceedings of the National Workshop on the Basic Issues in Life Science. Ha Noi: Hanoi Science and Technics Publishing House.

Thai, B. T., Do, N. V. \& Huynh, H. T. K. (1993). New Species of Earthworms of Genus Pheretima Kinberg, 1867 (Megascolecidae-Oligochaeta) from Yokdon, Daklak province. Tap Chi Sinh Hoc, 15(4), 12-15. 